Journal of Islamic Economics and Finance Studies

Volume 2, No. 1 (June, 2021), pp. 17-33

DOI http://dx.doi.org/10.47700/jiefes.v2i1.2731

ISSN $2723-6730$ (Print)

ISSN 2723 - 6749 (Online)

\title{
Profesionalitas Nazir Wakaf: \\ Studi Manajemen Wakaf Produktif di Lembaga Wakaf Daarut Tauhiid
}

\author{
Wildan Munawar \\ Universitas Djuanda Bogor \\ wildan.munawar@unida.ac.id
}

Diterima: 30 Maret 2021

Direvisi: 2 Juni 2021

Dipublikasi: 24 Juni 2021

\begin{abstract}
Nazir has a central role in management and development of waqf assets. A nazir's method of managing waqf assets will decide the quality and quantity of the use of waqf assets, so that the existence of a professional work team will make the waqf assets more developed and productive. The purpose of this study was to determine the professionalism of waqf nazir by analyzing the management of productive waqf in the Daarut Tauhiid Bandung waqf institution. This research used a qualitative descriptive approach by analyzing productive waqf management from three aspects, namely nazir, waqf assets, and finance at the Daarut Tauhiid waqf institution. The data collection techniques are observation, interviews, documentation, and literature study. The data analysis technique used interactive model analysis by Miles and Huberman. The findings of this study indicate that productive waqf management at the Daarut Tauhiid Waqf Institution, which is reflected in three aspects, namely nazir, asset management, and financial reporting has gone well. This is supported by professional and competent nazirs in managing and developing waqf assets productively through collaboration with various parties; as well as management of waqf finances in a transparent and accountable manner through reporting to BWI, the community and waqif.
\end{abstract}

Keywords: Assets Management; Finance Report; Professionalism of Nazir

\begin{abstract}
Abstrak
Nazir memiliki peran sentral dalam pengelolaan dan pengembangan aset wakaf. Cara nazir dalam memperlakukan aset wakaf akan menentukan kualitas dan kuantitas pemanfaatan aset wakaf, sehingga keberadaan tim kerja yang profesional menjadikan aset wakaf akan semakin berkembang dan produktif. Tujuan penelitian ini untuk mengetahui profesionalitas nazir wakaf dengan menganalisa manajemen wakaf produktif di lembaga wakaf Daarut Tauhiid Bandung. Metode penelitian ini menggunakan pendekatan deskriptif kualitatif dengan menganalisa manajemen wakaf produktif dari tiga aspek, yaitu nazir, aset wakaf, dan keuangan di lembaga wakaf Daarut Tauhiid. Adapun teknik pengumpulan data menggunakan observasi, wawancara, dokumentasi dan studi kepustakaan. Teknik analisis data menggunakan analisis model interaktif Miles dan Huberman. Temuan penelitian ini menunjukkan bahwa manajemen wakaf produktif di Lembaga Wakaf Daarut Tauhiid yang direfleksikan melalui tiga aspek yaitu nazir, pengelolaan aset, dan pelaporan keuangan telah berjalan dengan baik. Hal ini didukung oleh para nazir yang profesional dan kompeten dalam mengelola dan mengembangkan aset wakaf secara produktif melalui kerja sama dengan berbagai pihak, dan juga pengelolaan keuangan wakaf secara transparan dan akuntabel melalui pelaporan kepada BWI, masyarakat dan waqif.
\end{abstract}

Kata kunci: Pelaporan Keuangan; Pengelolaan Aset; Profesionalitas Nazir 


\section{PENDAHULUAN}

Wakaf produktif merupakan salah satu bentuk pengembangan wakaf yang mengarah kepada ekonomi. Pengembangan tersebut dilakukan dengan pemanfaatan aset atau harta benda wakaf yang bergerak maupun tidak bergerak. Dalam peranannya, wakaf yang difungsikan untuk kegiatan ekonomi sangat membantu dan berpengaruh besar dalam meningkatkan kesejahteraan masyarakat (Zuki, 2012; Bakhri, 2016). Beberapa negara diantaranya Bangladesh, Singapura, Turki, Malaysia, dan Mesir telah mengembangkan aset wakaf secara produktif. Bangladesh mampu mengembangkan wakaf tunai sebagai modal pembiayaan untuk usaha kecil dan menengah, pembiayaan mikro, pembiayaan konsumtif seperti pembiayaan murabahah, salam, istisna, ijarah dan pembiayaan lainnya serta pembiayaan investasi di pasar modal (Islam, 2015). Singapura juga telah membelanjakan kurang lebih $\$ 140$ juta untuk pembinaan 23 masjid besar, pembangunan 20 unit perumahan wakaf Kassim, gedung komersial, dan institusi pengembangan Wisma Indah di Changi Road. Turki dan Malaysia mengembangkan wakaf investasi dengan memperkenalkan skim saham wakaf, serta Mesir yang mampu memproduktifkan wakaf di berbagai bidang usaha (Ascarya, Rahmawati, \& Hosen, 2016).

Pengembangan wakaf produktif yang dijalankan oleh berbagai negara tersebut tidak terlepas dari peran nazir lembaga wakaf yang menerapkan prinsip manajemen profesional dan modern. Berdasarkan Yuli (2015) dan Bakhri (2016) pengelolaan wakaf secara produktif menjadi alternatif solusi dalam pengembangan dan pemberdayaan ekonomi dalam rangka meningkatkan kesejahteraan masyarakat. Namun kenyataannya pemanfaatan wakaf untuk ekonomi sangat kurang dirasakan oleh masyarakat, karena masih banyak pengurus atau nazir yang mengelola wakaf dengan sistem tradisional (Koto \& Saputra, 2016). Hal ini diperkuat dengan hasil penelitian Megawati (2014) bahwa penyebab pengelolaan wakaf secara tradisional diakibatkan beberapa faktor yaitu harta wakaf yang dikelola masih berpedoman pada tradisi pengelolaan usaha yang kaku dan kurang inovasi, menganggap profesi nazir sebagai pekerjaan sampingan yang bersifat sukarela, dan minimnya kompetensi nazir dalam mengelola dan mengembangkan harta wakaf.

Permasalahan dalam pengelolaan dan manajemen wakaf sangat penting untuk disoroti. Cukup banyak harta wakaf yang telantar dan bahkan ada sebagian harta wakaf yang hilang atau mati (Fauzia, 2018). Selain itu, umat Islam pada umumnya hanya mewakafkan tanah dan bangunan, sementara waqif kurang memikirkan biaya operasional dari bangunan tersebut (Hasanah, 2012). Oleh karena itu, peran nazir yang profesional sangat dibutuhkan dalam pengelolaan wakaf agar harta benda wakaf dapat dikembangkan secara produktif.

Lembaga wakaf Daarut Tauhiid merupakan salah satu lembaga wakaf di Indonesia yang sedang mengembangkan aset wakaf secara produktif. Bentuk pengembangannya meliputi berbagai bentuk seperti penyewaan kios usaha 
produktif kepada masyarakat sekitar, penyewaan gedung untuk kegiatan sekolah atau keagamaan, penyewaan cottage untuk penginapan, kerja sama dengan koperasi pondok pesantren melalui usaha Super Market Swalayan Daarut Tauhiid, kantin Belia Food untuk penyediaan makanan, dan lainnya. Pengembangan aset wakaf tersebut didukung oleh nazir lembaga wakaf Daarut Tauhiid yang mengelola secara profesional dan telah menunjukkan akuntabilitasnya kepada stakeholder. Selain itu, lembaga wakaf Daarut Tauhiid juga memiliki pengelolaan dan manajemen sendiri yang terpisah dengan lembaga ZIS. Sehingga harapannya nazir dapat lebih memfokuskan penghimpunan dan pengelolaan aset wakaf untuk lebih berkembang dan memberikan manfaat yang lebih besar lagi kepada masyarakat.

Penelitian ini akan memfokuskan pada manajemen wakaf produktif yang telah berjalan di lembaga wakaf Daarut Tauhiid. Hal ini dikarenakan ketika manajemen wakaf berjalan dengan baik secara produktif, maka akan tercipta nazir yang profesional. Novelty dari penelitian ini adalah temuan terkait pengelolaan wakaf produktif berdasarkan tiga aspek di Pesantren Daarut Tauhiid, yaitu profesionalitas nazir, pengelolaan asset dan pelaporan keuangannya. Hasil penelitian ini diharapkan memberikan kontribusi secara teoritis maupun praktis dalam pengembangan wakaf di Indonesia, khususnya dalam upaya peningkatan dan pengembangan profesionalitas nazir wakaf.

\section{TINJAUAN PUSTAKA}

\section{Manajemen Wakaf Produktif}

Dalam Islam maupun ilmu ekonomi, definisi manajemen tidak jauh berbeda. Manajemen dipandang sebagai ilmu dan seni kepemimpinan. Menurut Sinn (2008), manajemen dipandang sebagai kumpulan pengetahuan yang dikumpulkan, disistematisasi dan diterima berkenaan dengan kebenaran-kebenaran universal mengenai manajemen. Dalam sudut pandang seni, manajemen diartikan sebagai kekuatan pribadi yang kreatif ditambah skill dalam pelaksanaan juga merupakan seni organisator dan pemanfaat bakat manusia. Selain sebagai alat dan seni, manajemen juga memiliki dua unsur penting lainnya yakni subjek pelaku dan objek tindakan yang terdiri dari organisasi, sumber daya insani, dana, operasi/produksi, pemasaran, waktu dan objek lainnya. Dengan demikian, subjek pelaku dalam manajemen wakaf adalah nazir itu sendiri, sedangkan dalam objek tindakan bisa meliputi aset yang dikelola, dana wakaf yang dihimpun dan lainnya. Manajemen ini digunakan untuk mengatur kegiatan pengelolaan wakaf, menghimpun wakaf uang, dan menjaga hubungan baik antara nazir, waqif, dan masyarakat (Rozalinda, 2005).

Iman dan Muhammad (2014) mengatakan bahwa lembaga wakaf membutuhkan orang-orang dengan latar belakang pendidikan yang baik diantaranya memiliki pengalaman dalam mengikuti pelatihan profesional dan program sertifikasi. Maka tidak heran jika beliau menegaskan bahwa nazir menjadi salah satu hal yang dibutuhkan secara mendasar dalam manajemen wakaf (Khamis 
\& Salleh, 2018). Selain nazir, dua hal lainnya yang dibutuhkan dalam manajemen wakaf adalah pelaporan keuangan dan pengelolaan aset.

Pada dasarnya, dana wakaf diperoleh dari publik dan dikelola oleh nazir di bawah lembaga wakaf. Sebagai pihak perantara antara wakaf dan penerima manfaat, lembaga wakaf bertanggung jawab atas pengelolaan dana wakaf dan perlu mengungkapkan informasi yang cukup mengenai dana wakaf itu sendiri. Praktik pengungkapan yang baik oleh lembaga wakaf harus mencakup informasi keuangan dan non-keuangan untuk semua kegiatan yang terkait wakaf, program dan proyek yang dilakukan (Kamaruddin et.al., 2018).

Menurut Antonio (2011) salah satu filosofi dasar pengelolaan wakaf yang profesional adalah asas transparansi dan akuntabilitas. Hal ini sesuai dengan prinsip manajemen modern yang diajarkan oleh sifat Rasulullah saw yang empat yaitu tabligh (menyampaikan informasi yang benar/transparan). Konsep tabligh dalam manajemen menekankan kepada kemauan dan kemampuan menyampaikan segala informasi yang baik dan benar, termasuk di dalamnya menyampaikan laporan keuangan. Manajemen profesional harus dilakukan secara transparan, jujur dan bertanggung jawab, sehingga pihak yang mengatur seluruh aliran uang (bagian keuangan) siap untuk diaudit oleh pihak mana pun dan kapan pun juga (Direktorat Pemberdayaan Wakaf, 2013).

Dalam pengelolaan aset wakaf, nazir memiliki amanah untuk menjaga, merawat dan mengelola aset tersebut agar lebih produktif. Waqif dalam memberikan aset wakaf tentunya disertai dengan peruntukan wakaf. Misalnya, waqif menginginkan bahwa peruntukan tanah wakafnya adalah untuk kesehatan (pembangunan rumah sakit). Maka nazir harus berupaya agar keinginan waqif untuk didirikan rumah sakit tersebut dipenuhi. Selain itu juga, nazir harus memikirkan juga bagaimana memenuhi biaya operasional rumah sakit tersebut. Dalam rangka memenuhi biaya operasionalnya, nazir bisa mendirikan misalnya hotel di samping rumah sakit tersebut untuk menampung keluarga pasien yang ingin menemani pasien selama pasien dirawat di rumah sakit. Keuntungan dari hotel akan digunakan untuk membiayai operasional rumah sakit tersebut (DEKS BI, 2017).

\section{Nazir Profesional}

Keberhasilan wakaf tidak terlepas dari peran nazir yang mengelola wakaf secara profesional. Namun, pada kenyataannya mayoritas nazir masih berpegang teguh pada interpretasi fiqih tradisional Syafi'i, sehingga nazir tidak memiliki keterampilan manajerial atau tidak memiliki waktu yang tersedia untuk mengelola wakaf. Alasannya prinsip "tidak dapat diubah" dan "memiliki keabadian" yang mengakibatkan orang takut untuk mengembangkan aset wakaf sehingga pada akhirnya banyak yang dibiarkan rusak dan tidak digunakan. (Fauzia, 2018)

Dalam perwakafan, pengelola wakaf atau nazir sangat membutuhkan manajemen dalam menjalankan tugasnya. Manajemen diperlukan sebagai upaya 
agar kegiatan pengelolaan wakaf dapat berjalan secara efektif dan efisien (Rozalinda, 2005). Pendekatan manajemen merupakan suatu keniscayaan, apalagi jika dilakukan dalam suatu organisasi atau lembaga. Dengan organisasi yang rapi, akan tercapai hasil yang lebih baik daripada yang dilakukan secara individu. Oleh karena itu, organisasi apapun, termasuk lembaga wakaf, senantiasa membutuhkan manajemen yang baik. (Hafidhudin \& Tanjung, 2003; Abdullah, 2013)

Lembaga wakaf membutuhkan nazir yang sangat kompeten tidak hanya dalam manajemen tetapi juga dalam keuangan dan investasi syariah (Khamis \& Salleh, 2018). Nazir juga harus menjunjung tinggi konsep transparansi, produktivitas, dan integritas (Masyita \& Febrian, 2004). Selain itu, lembaga wakaf harus dikelola dengan memiliki pengetahuan dan keterampilan profesional untuk menjaga aset tetap produktif dan menghasilkan.

Nazir profesional dalam mengelola harta wakaf harus mengacu pada prinispprinsip manajemen modern. Menurut Rozalinda (2005), terdapat beberapa ciri atau karakteristik profesional nazir yang dapat dijadikan sebagai indikator nazir profesional antara lain:

1. Memiliki keahlian dan keterampilan khusus.

Keterampilan ini biasanya diperoleh dari pendidikan, pelatihan, dan pengalaman yang pernah dialami dalam jangka waktu tertentu. Pengetahun, keahlian dan keterampilan ini memungkinkan orang yang profesional mengenali dengan baik dan tepat persoalan-persoalan yang muncul dalam pekerjaannya dan mencari solusi yang tepat dari persoalan tersebut.

2. Komitmen moral yang tinggi.

Komitmen moral tersebut dapat dituangkan dalam bentuk kode etik profesi yang ditujukan untuk melindungi masyarakat dari kerugian dan kelalaian, baik disengaja, maupun tidak dan ditujukan untuk melindungi profesi tersebut dari perilaku-perilaku yang tidak baik.

3. Kompensasi yang layak.

Seorang yang profesional biasanya hidup dari profesi yang digelutinya. Dia dibayar dengan gaji yang layak sebagai konsekuensi dari pengerahan seluruh tenaga, pikiran, keahlian, dan keterampilan.

4. Pengabdian kepada masyarakat.

Seorang nazir yang profesional akan memegang teguh komitmen moral sebagaimana yang tertuang dalam kode etik profesi, sehingga profesi yang diembannya lebih mengutamakan kepentingan masyarakat daripada kepentingan dirinya.

5. Legalisasi sebagai nazir.

Nazir merupakan sebuah profesi yang menyangkut kepentingan orang banyak yang terkait dengan nilai-nilai kemanusiaan dan keislaman. Oleh karena itu, profesi tersebut harus menjadi profesi yang sah dan diizinkan. 


\section{METODE PENELITIAN}

Penelitian ini termasuk jenis penelitian lapangan dengan pendekatan kualitatif tentang manajemen wakaf produktif dari tiga aspek, yaitu nazir, aset wakaf, dan keuangan yang telah dijalankan oleh lembaga wakaf Daarut Tauhiid. Rancangan penelitian menggunakan rancangan studi kasus yaitu dengan mendeskripsikan manajemen wakaf produktif di lembaga wakaf Daarut Tauhiid secara rinci dan mendalam dengan sampel penelitian pimpinan lembaga wakaf Daarut Tauhiid. Adapun teknik pengumpulan data menggunakan observasi, wawancara mendalam, dokumentasi dan studi kepustakaan yang mendukung penelitian ini. Teknik analisis data menggunakan teknik deskriptif dengan mengambil model interaktif Miles dan Huberman melalui tiga langkah kegiatan yaitu reduksi data, penyajian data, dan penarikan kesimpulan.

\section{HASIL DAN PEMBAHASAN}

\section{Gambaran Umum Lembaga Wakaf Daarut Tauhiid}

Sejarah Wakaf Daarut Tauhiid dimulai ketika KH. Abdullah Gymnastiar memulai pengajian di sebuah kamar kos yang sekarang bangunannya telah berubah menjadi Masjid Daarut Tauhiid. Saat itu, Aa Gym mengajak semua jemaah yang ikut pengajian yang terdiri dari anak-anak muda untuk berwakaf tunai. Jemaah diberikan kupon wakaf sesuai dengan kemampuan dan keinginan mereka. Besaran nominal kupon tersebut terdiri dari Rp 1.000.000,-, Rp. 100.000,-, Rp. 10.000,- dan bahkan ada pula per lembarnya seharga Rp. 1.000,-. Dari dana wakaf yang terkumpul tersebut, kemudian dibelikan sebidang tanah untuk kepentingan umat dan diserahkan kepada nazir yang berasal dari jemaah Daarut Tauhiid (Hermawan, 2017). Dengan karunia Allah SWT, pada bulan Juli 1993 di atas tanah tersebut kemudian berdirilah sebuah masjid sebagai pusat kegiatan umat yang bernama Masjid Daarut Tauhiid. Pada awal berdirinya, Masjid Daarut Tauhiid dibangun menjadi dua lantai. Lantai satu dijadikan Super Mini Market (SMM) dan Warung Telepon (Wartel), sedangkan lantai duanya menjadi lantai utama salat.

Seiring perkembangan waktu, pengelolaan wakaf semakin kompleks dan dana wakaf semakin bertambah, maka pada tahun 1999 terbentuklah lembaga wakaf yang menyatu dengan lembaga zakat dan infak (ziswaf). Selain itu, aset wakafpun semakin bertambah setelah adanya tanah wakaf dari Koperasi Daarut Tauhiid yang sekarang menjadi gedung Yayasan Daarut Tauhiid. Beberapa waktu kemudian, tanah yang menjadi tempat asal mula berdirinya gedung Daarul Hajj diwakafkan oleh para jemaah haji. Selain itu, bertambah pula tanah wakaf lainnya yang saat ini menjadi tempat berdiri Dome Sentral 5 dan Cottage Daarul Jannah, Sekolah Menengah Kejuruan (SMK), Taman Kanak-Kanak (TK), Kantin Daarut Tauhiid, dan Eco Pesantren (Kumara et.al., 2019). 
Untuk lebih memfokuskan penghimpunan dan pengelolaan aset Wakaf Daarut Tauhiid, pada tahun 2009 dibentuklah Pusat Pengembangan (Pusbang) Wakaf Daarut Tauhiid yang terpisah dengan lembaga ZIS. Hal ini merupakan dampak dari perkembangan organisasi dan perubahan visi lembaga serta didukung dengan berkembangnya wakaf di Indonesia yaitu lahirnya Undang-Undang No. 41 Tahun 2004 tentang Wakaf dan Peraturan Pemerintah No. 42 Tahun 2006. Pada awal berdiri, Pusbang Wakaf berkantor di cottage. Akan tetapi, pada saat menjelang bulan Ramadan di tahun yang sama, Pusbang Wakaf pindah gedung bertempat di seberang Masjid Daarut Tauhiid lantai atas (Hermawan, 2017).

Pada tahun 2014, Pusbang Wakaf berubah menjadi Wakaf Daarut Tauhiid dengan lebih memfokuskan kepada penghimpunan dan pengelolaan dana wakaf, serta pengembangan aset wakaf untuk mencapai visi dan misi yang telah dirumuskan. Seiring perkembangan pengelolaan wakaf, pada tahun 2018 Wakaf Daarut Tauhiid diperbesar dengan adanya Kantor Perwakilan Wakaf Eco Pesantren yang berlokasi di Jalan Cigugur Girang No. 33 Kampung Pangsor, Desa Cigugur Girang, Kecamatan Parongpong, Bandung Barat dan Kantor Perwakilan Wakaf Daarut Tauhiid Jakarta yang berlokasi di Jalan Cipaku 1 No. 18, Kebayoran Baru, Jakarta Selatan. Kantor perwakilan Wakaf Eco Pesantren mengelola tanah wakaf seluas 3,5 hektare yang di atasnya dibangun gedung sekolah dan asrama serta Masjid Daarut Tauhiid Eco Pesantren (Masjid Rahmatan Lil Alamin). Sedangkan Kantor Wakaf Daarut Tauhiid Jakarta mengelola aset wakaf berupa Masjid Daarut Tauhiid Jakarta, tanah wakaf Serua yang di atasnya berdiri Masjid Daarut Tauhiid Serua dan Sekolah Adzkia Islamic School, dan tanah wakaf di Tigaraksa Tangerang (Kumara et.al., 2019).

\section{Manajemen Wakaf Produktif di Lembaga Wakaf Daarut Tauhiid}

1. Profesionalitas Nazir Wakaf

Undang-undang wakaf di Indonesia membagi bentuk nazir dalam tiga bagian, yaitu nazir perorangan, nazir organisasi, dan nazir badan hukum. Syarat menjadi nazir harus memenuhi beberapa ketentuan yaitu warga negara Indonesia, beragama Islam, dewasa, amanah, mampu secara jasmani dan rohani, serta tidak terhalang melakukan perbuatan hukum. Syarat ini berlaku bagi nazir perseorangan, organisasi maupun badan hukum. Akan tetapi, bagi nazir organisasi dan badan hukum mengharuskan organisasi dan badan hukum tersebut bergerak di bidang sosial, pendidikan, kemasyarakatan, dan/atau keagamaan Islam. Khusus bagi badan hukum, diharuskan dibentuk sesuai dengan peraturan perundang-undangan yang berlaku. Berdasarkan hasil observasi, nazir lembaga wakaf Daarut Tauhiid termasuk dalam kategori nazir badan hukum, karena berada dalam naungan Yayasan Daarut Tauhiid. Yayasan Daarut Tauhiid merupakan organisasi badan hukum yang bergerak dalam bidang sosial, pendidikan, dan keagamaan Islam. Nazir berbadan hukum ini 
menjadi salah satu proses dalam pengembangan wakaf secara profesional (Huda, 2012).

Profesionalitas nazir Lembaga wakaf Daarut Tauhiid dapat dilihat dari kedisiplinan waktu bekerja. Para nazir bekerja secara sepenuh waktu sesuai dengan jam kerja yang telah ditetapkan. Selain itu, masing-masing nazir diberikan tugas dan wewenang sesuai dengan yang diamanahkan oleh lembaga. Oleh karena itu, agar memiliki legalitas resmi dari lembaga negara, pihak lembaga wakaf Daarut Tauhiid mendaftarkan nazir wakaf pada Badan Wakaf Indonesia. Para nazir yang didaftarkan meliputi ketua pengurus yayasan Daarut Tauhiid bernama Gatot Kunta Kumara, Sekretaris pengurus yayasan Daarut Tauhiid Yunus Zainudin, dan Bendahara yayasan Daarut Tauhiid bernama Muhammad Iskandar.

Dalam rangka peningkatan profesionalitas, para nazir dibekali dengan pelatihan-pelatihan untuk peningkatan kompetensi dan pengetahuan terhadap pengelolaan wakaf. Hafidhudin dan Tanjung (2003) menegaskan pelatihan yang biasa dilakukan sebuah lembaga pada dasarnya bermuara pada tiga hal, yaitu pengetahuan, keterampilan, dan sikap. Pelatihan-pelatihan juga harus diarahkan untuk membangun motivasi disamping hal-hal yang sifatnya teknis, karena peningkatan kualitas pekerjaan juga didorong oleh faktor-faktor internal yang kuat dari dalam diri. Menurut Sinn (2008), Islam telah mendorong untuk melakukan pelatihan terhadap para karyawan termasuk nazir wakaf dengan tujuan mengembangkan kompetensi dan kemampuan teknis nazir dalam menyelesaikan tugas dan tanggung jawab pekerjaannya. Sebagaimana Rasulullah saw. memberikan pelatihan terhadap orang yang diangkatnya yaitu Ali bin Abi Thalib untuk mengurusi persoalan kaum muslim dan membekalinya dengan nasihat-nasihat dan beberapa petunjuk.

Nazir lembaga wakaf Daarut Tauhiid diberikan pelatihan-pelatihan yang sesuai dengan bidangnya. Nazir bidang fundraising wakaf, diberikan pelatihan yang berhubungan dengan fundraising. Begitu pula dengan nazir bagian akuntansi, maka diberikan pelatihan tentang akuntansi wakaf. Apabila terdapat nazir yang kurang memahami tentang wakaf produktif, pihak lembaga memberikan materi tentang fiqih wakaf baik pemateri dari internal wakaf Daarut Tauhiid maupun eksternal, seperti Badan Wakaf Indonesia (BWI). Pelatihan-pelatihan tersebut kadang dilakukan satu bulan sekali, satu bulan tiga kali bahkan sampai empat kali. Pelatihan ini bertujuan untuk meningkatkan kompetensi dan keilmuan nazir, sehingga mampu meningkatkan kinerja dan profesionalnya dalam memberikan pelayanan kepada masyarakat. Karena nazir tersebut pada awalnya tidak berkonsentrasi pada wakaf, maka mereka perlu memahami dan mengerti konsep wakaf produktif dengan adanya pelatihanpelatihan. Hal ini berdasarkan pernyataan wawancara dari Bapak Agus selaku Direktur Marketing dan Komunikasi. 
Kita ada pelatihan-pelatihan. Kita namanya ada skill matriks. Skill matriks adalah pelatihan sesuai dengan bidangnya. Kalau dia bidang fundraising wakaf, diberikan pelatihan yang berhubungan dengan fundraising. Ketika berhubungan dengan akuntansi wakaf, kita berikan juga pelatihan tentang akuntansi wakaf. Materi tentang wakaf produktif, kita hadirkan fiqih wakaf, kita hadirkan dari BWI. Jadi pelatihan-pelatihan kita sesuaikan dengan skill matriks mereka. Manajemen ya manajemen. Pelatihannya kadang dilakukan sebulan sekali, kadang juga sebulan bisa tiga sampai empat kali. Diselenggarakan oleh bagian SDI dan SDM yang berhubungan dengan wakaf. Dampaknya mereka lebih paham bagaimana melayani tamu, fundraising, bagaimana ketika mengomunikasikan. Dengan adanya pelatihan mereka harus meningkatkan kinerjanya.

Nazir wakaf Daarut Tauhiid dalam memberikan pelayanannya kepada masyarakat dituntut untuk sesuai dengan Standar Operasional Prosedur (SOP) yang ditetapkan. Karena wakaf Daarut Tauhiid telah masuk dalam standar ISO 2015 sehingga mewajibkan setiap aktifitasnya sesuai dengan SOP-nya. Adanya SOP dalam standar ISO 2015 ini diharapkan mampu meningkatkan kepercayaan masyarakat. Selain figur Aa Gym yang menjadi daya tarik masyarakat, diharapkan dengan adanya manajemen yang baik menjadikan lembaga wakaf Daarut Tauhiid masih terus bertahan hingga jangka panjang. Selain itu, nazir wakaf juga selalu dianjurkan untuk melakukan salat berjamaah. Karena selain dia harus memberikan pelayanan yang baik kepada masyarakat, juga mampu menjaga hubungannya kepada Allah SWT.

Dari segi upah, kompensasi yang diterima oleh nazir Lembaga Wakaf Daarut Tauhiid sesuai Upah Minimum Regional (UMR) yang ditetapkan daerah setempat yaitu kota Bandung. Berdasarkan Surat Keputusan Gubernur Jawa Barat Nomor 561/kep1220-yanbangsos/2018 tentang Upah Minimum Kabupaten/Kota (UMK) di daerah Provinsi Jawa Barat tahun 2019, besaran UMK Kota Bandung tahun 2019 sebesar Rp 3.339.580,61. Selain sesuai ketetapan UMK, penetapan upah juga disesuaikan dengan kondisi, tanggung jawab dan jenis pekerjaan. Upah yang ditentukan berdasarkan jenis pekerjaan ini merupakan asas pemberian upah sebagaimana ketentuan yang dinyatakan Allah swt. dalam firman-Nya pada QS. Al-Ahqaf: 19.

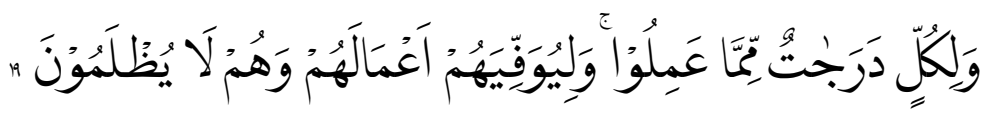

Setiap orang memperoleh tingkatan sesuai dengan apa yang telah mereka kerjakan dan agar Allah menyempurnakan balasan amal mereka serta mereka tidak dizalimi.

Oleh karena itu, upah yang dibayarkan kepada masing-masing pegawai bisa berbeda berdasarkan jenis pekerjaan dan taggung jawab yang dipikulnya. Rasulullah saw. dan para khalifah juga dalam menetapkan upah menggunakan prinsip pertengahan, moderat, tidak berlebih-lebihan atau terlalu sedikit (proporsional) (Sinn, 2008). Tujuan utama pemberian upah tersebut diharapkan 
mampu meningkatkan kinerja nazir dan memenuhi segala kebutuhan pokok. Sehingga mereka tidak terdorong untuk melakukan tindakan yang tidak dibenarkan untuk sekadar memenuhi nafkah dan keluarganya, apalagi nazir di lembaga wakaf yang memprioritaskan kepercayaan dari masyarakat.

2. Pengelolaan Aset Wakaf

Aset wakaf merupakan harta benda yang diberikan oleh waqif kepada nazir untuk dikelola sesuai dengan peruntukkannya. Istilah benda atau harta yang diwakafkan dalam literatur fiqih disebut dengan mauquh bih. Aset wakaf ini menjadi salah satu rukun yang harus ada dalam pelaksanaan wakaf. Lembaga wakaf Daarut Tauhiid telah memiliki aset wakaf lebih dari 40 aset wakaf yang berada di berbagai daerah seperti Bandung, Jakarta, Tangerang, Kuningan, Subang, Yogyakarta, dan Kalimantan. Dari keseluruhan aset tersebut, sekitar $80 \%$ telah memiliki sertifikat wakaf. Sedangkan sisanya dalam proses pengajuan. Aset yang terdapat di sekitar kantor wakaf DT sebagian ada yang disewakan kepada masyarakat dan ada pula yang digunakan untuk pendidikan, pelatihan, dan kegiatan-kegiatan lain yang sifatnya kondisional. Aset yang disewakan seperti bazar pertokoan wakaf Daarut Tauhiid, kios-kios, gedung aula serba guna disewakan untuk kegiatan-kegiatan umum, serta cottage yang digunakan untuk penginapan. Penyewaan aset-aset wakaf tersebut ditujukan untuk mengembangkan aset wakaf lainnya dan juga membantu operasional lembaga dalam keberlanjutan pengelolaan wakaf.

Lembaga Wakaf Daarut Tauhiid dalam pengelolaan aset wakaf memiliki visi makmur dan produktif. Makmur artinya bahwa setiap aset wakaf yang dikelola oleh Daarut Tauhiid harus memberikan kemanfaatan secara luas kepada umat dan masyarakat, tidak hanya secara finansial. Maka aset-aset tersebut digunakan untuk kepentingan umat atau hasilnya diproyeksikan untuk program-program yang sifatnya nonkomersial, seperti asrama pesantren tahfidz Al-Qur'an, Santri Siap Guna (SSG), dan acara-acara kajian, ceramahceramah, dan lain sebagainya. Sedangkan produktif adalah bahwa aset yang dikelola harus mendatangkan nilai tambah secara ekonomi. Daarut Tauhiid menempatkan hampir 40 - 50\% asetnya untuk dikelola secara produktif sehingga hasilnya dapat dipergunakan untuk membiayai program-program pesantren dan operasional pesantren. Oleh karena itu, Daarut Tauhiid memiliki kantor kas perbankan syariah, Anjungan Tunai Mandiri (ATM), toko swalayan, penginapan, counter-counter niaga, dan lain-lain. Usaha-usaha tersebut hadir dengan konsep kerja sama, baik sistem bagi hasil atau sewa terhadap aset wakaf yang digunakan. Secara rinci, bentuk-bentuk kerja sama yang dilakukan Lembaga Wakaf Daarut Tauhiid dalam rangka pengelolaan dan pengembangan aset wakaf adalah sebagai berikut:

a. Kerja Sama Sewa Menyewa

Kerja sama sewa menyewa merupakan investasi harta wakaf secara langsung dengan menggunakan akad ijarah. Penyewaan harta wakaf harus 
sesuai dengan ketentuan yang terdapat dalam akad ijarah, seperti ketentuan mengenai pelaksanaan sewa, harta yang disewakan, jangka waktu penyewaan, dan waktu berakhirnya penyewaan. Para ahli fikih berpendapat bahwa nazir dapat menyewakan harta wakaf sesuai harga pasar atau harga yang lazimnya diberikan. Nazir tidak boleh menyewakan harta wakaf dengan harga di bawah harga pasar, kecuali jika hanya sedikit perbedaan harganya (Maria et.al., 2019). Lembaga Wakaf Daarut Tauhiid mengelola aset wakaf dalam bentuk kerja sama dengan sistem akad sewa dilakukan dengan pihak ketiga (masyarakat atau perusahaan) atas aset yang bernilai komersial. Aset-aset wakaf yang disewakan Wakaf Daarut Tauhiid yaitu Anjungan Tunai Mandiri (ATM), pertokoan bazar wakaf produktif dan kios di sekitar Jalan Geger Kalong, serta pujasera yang digunakan untuk usaha warung nasi dan gorengan yang bertempat di dekat lapangan parkiran.

b. Kerja Sama Bagi Hasil

Kerja sama bagi hasil merupakan bentuk kerja sama dalam mengelola aset wakaf yang dapat menggunakan akad mudharabah dan musharakah. Kedua akad ini berbentuk perkongsian modal dan usaha atas suatu proyek yang dijalankan dengan membagi keuntungan dan kerugian sesuai proporsi yang telah disepakati. Kahf menyatakan bahwa akad mudharabah dapat digunakan apabila nazir memegang peranan sebagai pihak yang menjalankan usaha. Sementara dalam akad musharakah, pihak lembaga wakaf dapat menawarkan kepada pihak pengembang untuk membuat bangunan di atas tanah wakaf. Harga tanah wakaf dan bangunan harus ditetapkan pada saat kontrak dilakukan, sehingga modal kerja sama dapat disesuaikan dengan besarnya nilai tanah wakaf dan bangunan tersebut (Maria et.al., 2019). Lembaga Wakaf Daarut Tauhiid sebagai pengelola wakaf tidak hanya menggunakan akad sewa menyewa dalam mengelola aset wakafnya, tetapi juga menggunakan kerja sama bagi hasil. Bentuk kerja sama pengelolaan aset wakaf dilakukan dengan pihak koperasi pondok pesantren Daarut Tauhiid. Yayasan Daarut Tauhiid menyerahkan aset wakafnya kepada koppontren untuk mengelola dan mengatur manajemennya sehingga menghasilkan keuntungan. Atas keuntungan tersebut, setiap tahun pihak Daarut Tauhiid mendapatkan bagi hasil. Adapun aset wakaf yang dikerjasamakan dengan sistem bagi hasil adalah cottage Daarul Jannah, toko Super Mini Market (SMM), dan kantin.

c. Kerja Sama Outsourcing

Outsourcing adalah pendelegasian operasi dan manajemen harian dari suatu proses bisnis kepada pihak luar (perusahaan penyedia jasa outsourcing). Dengan metode ini, maka pengelolaan tidak dilakukan oleh lembaga, melainkan dilimpahkan kepada perusahaan jasa outsourcing (Damanik, 2006). Lembaga Wakaf Daarut Tauhiid menerapkan kerja sama 
outsourcing dalam pengelolaan aset wakaf. Hal ini agar mendatangkan keuntungan tanpa perlu menangani langsung dalam pengelolaannya. Adapun aset wakaf yang dikerjasamakan yaitu lahan parkir dan perkebunan. Dari pengelolaan aset tersebut, pihak Daarut Tauhiid setiap bulan atau setiap tahunnya mendapatkan nilai finansial tanpa dibebani dengan penyediaan modal dan pengelolaan.

d. Kerja Sama Advertising

Kerja sama dalam bentuk advertising dilakukan dengan memanfaatkan lahan dan area yang berada di Daarut Tauhiid untuk promosi pihak ketiga (masyarakat atau perusahaan) atau lembaga internal Daarut Tauhiid. Dalam kerja sama ini, nilai manfaat keuangan terkadang tidak menjadi pertimbangan utama karena pola kerja sama ini dilakukan untuk mendukung program kerja sama yang lebih strategis dengan lembaga atau pihak lain.

Bentuk-bentuk kerja sama yang dilakukan oleh Lembaga Wakaf Daarut Tauhiid dalam mengelola dan mengembangkan aset wakaf di atas menunjukkan bahwa pemberdayaan aset wakaf Daarut Tauhiid mengarah kepada peningkatan ekonomi. Hal ini sesuai dengan pernyataan Zarqa yang mengemukakan bahwa tujuan menginvestasikan harta wakaf adalah menghasilkan sebanyak mungkin pendapatan yang dapat menambah nilai harta wakaf dan memberikan manfaat sebagaimana yang diharapkan masyarakat. Dari aspek ekonomi, investasi harta wakaf berarti mengupayakan harta wakaf dalam berbagai kegiatan investasi untuk mencapai tujuan wakaf dan menjaga atau memelihara kekekalan wakaf (Maria et.al., 2019). Suhaimi, Rahman, dan Marican (2014) juga menegaskan dengan adanya fasilitas atau aset untuk pengembangan sumber daya manusia dari segi ekonomi berkontribusi terhadap peningkatan kualitas hidup komunitas muslim di Malaysia.

3. Pelaporan Keuangan

Pelaporan keuangan merupakan salah satu unsur dari dimensi akuntabilitas dan transparansi yang harus dijalankan oleh sebuah lembaga wakaf. Karena akuntabilitas lembaga wakaf akan berdampak terhadap semakin kuatnya legitimasi sosial dan menaikkan public trust serta dukungan masyarakat dalam pengelolaan wakaf (Yuliani \& Bustamam, 2017; Budiman, 2011). Dalam penelitian ini, akuntabilitas yang ditekankan terletak pada aspek financial. Broadbent, Dietrich, dan Laughin dalam Siraj dan Karbhari (2014) mengungkapkan bahwa sistem akuntabilitas keuangan berkaitan dengan apakah dana dan sumber daya publik digunakan dengan cara yang sesuai dan dapat diterima secara hukum. Sistem akuntabilitas keuangan yang dilakukan lembaga wakaf harus menerapkan sistem manajemen keuangan yang tepat dalam memastikan penggunaan sumber daya keuangan yang tepat. Karena lembaga wakaf merupakan lembaga yang mengelola dana publik yang sangat 
bergantung pada sumbangan publik, sehingga diperlukan membuat keputusan yang tepat untuk keberlanjutan lembaga di masa depan. Penyediaan informasi keuangan yang dapat diandalkan melalui pencatatan dan audit juga merupakan bagian dari sistem akuntabilitas keuangan.

Lembaga wakaf Daarut Tauhiid sebagai lembaga yang mengelola dana wakaf sangat menjunjung tinggi akuntabilitas dan transparansi dalam keuangan. Menurut Arianto (2011) suatu lembaga dapat dikatakan transparan apabila memenuhi indikator transparansi berikut ini yaitu pihak pemegang kepentingan (manajemen, karyawan, masyarakat, dan pemerintah) memperoleh informasi keuangan yang relevan secara berkala dan teratur, proses pengumpulan dan pelaporan informasi operasional lembaga telah dilakukan oleh unit organisasi dan karyawan secara terbuka dan objektif dengan tetap menjaga kerahasiaan lembaga, tersedia laporan pertanggungjawaban yang tepat waktu, menyampaikan laporan keuangan dan kinerja kepada publik dan instansi yang berwenang secara rutin, dan terdapat sistem pemberian informasi kepada publik. Berdasarkan indikator-indikator di atas, lembaga wakaf Daarut Tauhiid telah berupaya untuk transparan dalam menyampaikan laporan keuangannya. Bentuk transparansi aspek financial dapat tergambarkan dalam pelaporan keuangan yang secara rutin dilakukan oleh lembaga wakaf Daarut Tauhiid. Berikut ini bentuk-bentuk pelaporan keuangan wakaf Daarut Tauhiid.

a. Pelaporan Kepada Badan Wakaf Indonesia sebagai Regulator

Pelaporan pengelolaan wakaf merupakan kewajiban yang harus dilakukan oleh setiap lembaga wakaf sesuai dengan peraturan menteri agama nomor 73 tahun 2013. Pelaporan tersebut meliputi pelaksanaan pengelolaan, pengembangan, dan penggunaan hasil pengelolaan yang dilakukan secara periodik setiap 6 (enam) bulan sekali. Lembaga wakaf Daarut Tauhiid sebagai nazir yang terdaftar pada Badan Wakaf Indonesia memiliki kewajiban untuk melaporkan pengelolaan wakafnya kepada Badan Wakaf Indonesia dan Kantor Wilayah Kementerian Agama Provinsi Jawa Barat. Menurut Bapak Agus selaku direktur marketing dan komunikasi Wakaf Daarut Tauhiid, lembaga wakaf Daarut Tauhiid setiap 6 bulan secara rutin menyampaikan laporan pengelolaannya kepada BWI. Laporan tersebut berisi jenis harta benda wakaf yang dikelola baik harta benda bergerak maupun benda bergerak kecuali wakaf uang, bentuk pemanfaatan harta benda wakaf bergerak dan tidak bergerak, hasil pengelolaan harta benda wakaf bergerak dan tidak bergerak, dan penggunaan hasil pengelolaan harta benda wakaf bergerak dan tidak bergerak. Pelaporan kepada Badan Wakaf Indonesia ini merupakan komitmen wakaf Daarut Tauhiid sebagai bentuk akuntabilitas dan transparansi dalam mengelola lembaga wakaf yang diharapkan dapat terus meningkatkan kepercayaan masyarakat kepada Lembaga Wakaf Daarut Tauhiid. Hal ini didukung oleh hasil 
penelitian Athifah, Bayinah, dan Bahri (2018) yang menunjukkan bahwa secara bersamaan akuntabilitas publik dan transparansi laporan keuangan berpengaruh positif terhadap kepercayaan donatur.

b. Pelaporan Melalui Media Digital dan Elektronik Wakaf Daarut Tauhiid Pelaporan keuangan melalui media digital dan elektronik dilakukan dalam rangka mempermudah akses masyarakat umum terhadap keuangan wakaf Daarut Tauhiid. Selain keuangan, pihak wakaf Daarut Tauhiid juga melaporkan perkembangan wakaf yang melingkupi program dan juga pencapaian yang telah dilakukan wakaf Daarut Tauhiid. Pelaporan melalui media digital yang digunakan seperti televisi (MQ TV), radio dan media sosial lainnya seperti facebook, twitter dan instagram. Sedangkan pada media elektronik, wakaf Daarut Tauhiid rutin melaporkan keuangan penerimaan dan penyaluran dana wakaf melalui koran dan majalah. Majalah wakaf Daarut Tauhiid juga dapat dibaca di aplikasi smartphone dan tablet android. Bentuk pelaporan melalui media digital dan aplikasi tersebut merupakan bentuk inovasi wakaf Daarut Tauhiid dalam melakukan transparansi atas laporan pengelolaan wakaf, termasuk dalam laporan keuangan. Harapannya dengan media ini akan semakin memudahkan masyarakat dalam mengetahui pengelolaan wakaf di Wakaf Daarut Tauhiid.

c. Pelaporan Secara Langsung Kepada Masyarakat

Bentuk pelaporan secara langsung kepada masyarakat merupakan rutinitas yang dilakukan lembaga wakaf Daarut Tauhiid dalam menyampaikan laporan pengelolaan wakaf. Pelaporan ini dilakukan setiap minggu pada hari jum'at dan setiap kajian Aa Gym pada kamis malam. Pada pelaporan tersebut, disampaikan jumlah penghimpunan dan penggunaan dana wakaf, program-program yang sedang berjalan dan akan dijalankan oleh wakaf Daarut Tauhiid, misalnya saat ini, wakaf Daarut Tauhiid sedang melakukan program wakaf pembebasan lahan seluas 5 ha atau $50.000 \mathrm{~m}^{2}$ yang berlokasi di Jalan Tugu, Desa Karyawangi Kecamatan Parongpong Kabupaten Bandung Barat. Lahan ini akan digunakan untuk perluasan pesantren Daarut Tauhiid yang nantinya dibangun pesantren muslimah berwawasan lingkungan. Pelaporan secara langsung tersebut dilakukan sebagai bentuk transparansi kepada masyarakat yang kemungkinan tidak dapat mengakses melalui media digital atau elektronik. Pelaporan secara langsung pula merupakan langkah praktis yang ditujukan kepada masyarakat yang rutin mengikuti kajian Aa Gym dan jemaah yang aktif mengikuti kegiatan di masjid Daarut Tauhiid. 


\section{SIMPULAN}

Manajemen wakaf produktif di Lembaga Wakaf Daarut Tauhiid yang direfleksikan melalui tiga aspek yaitu profesionalitas nazir, pengelolaan aset, dan pelaporan keuangan telah berjalan dengan baik. Profesionalitas nazir lembaga wakaf Daarut Tauhiid dibuktikan dengan legalitas nazir yang berbadan hukum dan telah terdaftar pada BWI, kedisiplinan waktu bekerja, serta terselenggaranya pendidikan dan pelatihan yang menunjang meningkatkan pengetahuan dan keterampilan nazir. Selain itu, pelayanan yang diberikan mengacu kepada standar yang ditetapkan oleh sistem manajemen mutu ISO 9001:2015, dan standar ketentuan upah yang diberikan sesuai dengan Upah Minimum Kota (UMK) Bandung. Dari segi pengelolaan aset, lembaga wakaf Daarut Tauhiid telah memiliki aset lebih dari 40 aset wakaf yang tersebar di berbagai daerah di Indonesia. Aset-aset wakaf tersebut kemudian dimanfaatkan oleh masyarakat melalui penyewaan. Selain itu, terdapat pula aset-aset wakaf lainnya yang dikerjasamakan dengan lembaga keuangan dan koperasi pondok pesantren. Lembaga wakaf Daarut Tauhiid juga mengembangkan aset wakaf dalam bidang-bidang lain seperti pendidikan, keagamaan, dan sosial. Adapun dari segi pelaporan keuangan, lembaga wakaf Daarut Tauhiid melaporkan keuangan dalam tiga bentuk yaitu pelaporan kepada BWI, pelaporan kepada masyarakat dan waqif melalui media digital dan elektronik, dan pelaporan kepada masyarakat secara langsung melalui kajian dan kegiatankegiatan pesantren Daarut Tauhiid.

Untuk pengembangan penelitian selanjutnya, direkomendasikan melakukan kajian kuantitatif terkait pengukuran tingkat profesionalitas nazir untuk mendapatkan gambaran tingkat profesionalitas nazir secara umum. Melalui kajian yang komprehensif, diharapkan upaya peningkatan dan pengembangan profesionalitas nazir dapat lebih dioptimalkan.

\section{DAFTAR PUSTAKA}

Abdullah, M. M. (2013). Manajemen Berbasis Syariah. Yogyakarta: Aswaja Pressindo.

Arianto, A. (2011). Etika Bisnis Bagi Pelaku Bisnis. Jakarta: Rajawali Pers.

Ascarya, Rahmawati, S., \& Hosen, N. (2016). Merancang Model-Model Wakaf Produktif. International Seminar and The 2nd JIMF Call for Papers 2016 (pp. 1-99). Jakarta: Departemen Ekonomi dan Keuangan Syariah Bank Indonesia.

Athifah, Bayinah, A. N., \& Bahri, E. S. (2018). Pengaruh Akuntabilitas Publik dan Transparansi Laporan Keuangan Terhadap Kepercayaan Donatur pada Yayasan PPPA Daarul Qur'an Nusantara. Perisai: Islamic Banking and Finance Journal, 2(1), 54-74. 
Bakhri, A. (2016). Peranan Wakaf Produktif Pemuda Muhammadiyah untuk Kesejahteraan Warga Desa Longkeyang, Bodeh, Pemalang. Indonesian Journal of Islamic Literature and Muslim Society, 1(2), 199-214.

Budiman, A. A. (2011). Akuntabilitas Pengelola Lembaga Wakaf. Jurnal Walisongo, 19(1), 75-102.

Damanik, S. (2006). Outsourcing \& Perjanjian Kerja Menurut UU Nomor 13 Tahun 2003 tentang Ketenagakerjaan. Jakarta: DSS Publishing.

DEKS BI. (2017). Wakaf: Pengaturan dan Tata Kelola yang Efektif. Jakarta: Departemen Ekonomi dan Keuangan Syariah BI-Departemen Ekonomi Syariah Fakultas Ekonomi dan Bisnis.

Direktorat Pemberdayaan Wakaf. (2013). Paradigma Baru Wakaf di Indonesia, Jakarta: Kementerian Agama Republik Indonesia.

Fauzia, A. (2018). Waqf Making and Commercial Cemeteries: Religious Circulation and Commodification of the Economy of Giving: Waqf Making and Commercial Cemeteries. The Muslim World, 108(4), 676-701.

Hafidhudin, D., \& Tanjung, H. (2003). Manajemen Syariah Dalam Praktik. Jakarta: Gema Insani Press.

Hasanah, Uswatun. (2012). Urgensi Pengawasan Dalam Pengelolaan Wakaf Produktif. Al-Ahkam: Jurnal Pemikiran Hukum Islam, 22(1), 61-80.

Hermawan, W. (2017). Pengembangan Wakaf di Pusat Pengembangan Wakaf Daarut Tauhiid. Jurnal Pendidikan Agama Islam-Ta'lim, 15(1), 1-15.

Huda, M. (2012). Wakaf Dan Kemandirian Pesantren Dari Tebuireng Hingga Gontor. Jurnal Islamica, 7(1), 211-231.

Islam, M. M. (2015). Cash-Waqf: New Financial Instrument for SMEs Development in Bangladesh. World Vision Research Journal, 9(1), 111-120.

Kamaruddin, M. I., et.al. (2018). Financial and Non-Financial Disclosure Practices in Selected Awqaf Institutions. International Journal of Nusantara Islam, 6(1), 52-72.

Khamis, S. R., \& Salleh, M. C. (2018). Study On The Efficiency of Cash Waqf Management In Malaysia. Journal of Islamic Monetary Economics and Finance, 4(1), 61-84.

Koto, A., \& Saputra, W. (2016). Wakaf Produktif di Negara Sekuler: Kasus Singapura dan Thailand. Jurnal Sosial Budaya, 13(2), 126-139.

Kumara, G. K., et.al. (2019). Selayang Pandang Daarut Tauhiid Perjalanan Dakwah Dari Masa ke Masa. Bandung: Emqies Publishing.

Maria, D., et.al. (2019). Akuntansi dan Manajemen Wakaf. Jakarta: Salemba Empat.

Masyita, D., \& Febrian, E. (2004). The Role of BRI in the Indonesian Cash Waqf House's System. BRI International Seminar on Developing Microbanking: Creating Opportunities for the Poor through Innovatio. Denpasar. 
Megawati, D. (2014). Pengelolaan dan Pengembangan Wakaf Produktif di Kota Pekanbaru. Jurnal Hukum Islam, 14(1), 104-124.

Rozalinda. (2005). Manajemen Wakaf Produktif. Jakarta: Rajawali Pers.

Sinn, A. I. (2008). Manajemen Syariah: Sebuah Kajian Historis Dan Kontemporer. Jakarta: PT RajaGrafindo Persada.

Siraj, S. A., \& Karbhari, Y. (2014). Financial Accountability of Waqf (Pious Endowment) Institutions in Malaysia: The Case of Budgeting Practices in State Islamic Religious Councils. 1-24.

Suhaimi, F. M., \& et.al. (2014). The Role of Share Waqf in The Socio-Economic Development of The Muslim Community: The Malaysian Experience. Humanomics, 30(3), 227-254.

Yuli, S. B. (2015). Optimalisasi Peran Wakaf dalam Pemberdayaan Usaha Mikro, Kecil, dan Menengah (UMKM). Jurnal Ekonomika-Bisnis, 6(1), 1-15.

Yuliani, N. W., \& Bustamam. (2017). Akuntabilitas dan Transparansi Pengelolaan Aset Wakaf pada Baitul Mal Kota Banda Aceh. Jurnal Ilmiah Mahasiswa Ekonomi Akuntansi (JIMEKA), 2(4), 75-83.

Zuki, M. S. (2012). Waqf and Its Role In Socio-Economic Development. ISRA International Journal of Islamic Finance, 4(2), 173-178. 